Ирена П. АРСИЋ ${ }^{*}$

Универзитет у Нишу Филозофски факултет
Оригинални научни рад

Примљен: 23. 10. 2018.

Прихваћен: 14. 02. 2019.

\title{
ПАВЛЕ ПОПОВИЋ И „НОВА ДУБРОВАЧКА ПЛЕЈАДА”
}

Боравећи у Дубровнику, ради истраживања старе дубровачке књижевности, Павле Поповић је био у прилици да се упознаје са радом и настојањима припадника савременог дубровачког литерарног и, уопште, интелектуалног круга, међу којима посебно са Антуном Фабрисом и Иваном Стојановићем. Поред тога, последње године живота Матије Бана била су инспирација П. Поповићу да пише о његовом литерарном кругу у Дубровнику половином XIX века. Коначно, Дубровчани, филолози и историчари, међу којима најистакнутији Милан Решетар и Петар Колендић, са Павлом Поповићем су сарађивали или су били посвећени заједничким научним преокупацијама. Циљ овог рада је да изложи, на основу објављених текстова, став Павла Поповића према дубровачким писцима, научницима и интелектуалцима новијег доба, односно према „новој дубровачкој плејади”, како ју је сам једном насловио.

Кључне речи: Павле Поповић, Дубровник, Матија Бан, Антун Фабрис, новија дубровачка књижевност.

Године 1899, инспирисан архивским истраживањима Константина Јиречека, 31-годишњи Павле Поповић, професор гимназије, стиже у Дубровник да започне своја вишедеценијска проучавања старе дубровачке књижевности.

Сећања преточена у мемоаре немачке књижевнице, Иде фон Дирингсфелд (1815-1876), била су извор за Поповићево уживљавање у Дубровник половине 19. века који је, у односу на онај у који је он тада стигао, био много активнији у културном и научном смислу. Ослањајући се на њене импресије о врло оригиналним личностима тадашњег дубровачког интелектуалног круга, Поповић је међу онима које је у Дубровнику срела ова књижевница препознао први значајни покрет од како је Аустрија завладала, односно нову „Плејаду дубровачких песника и књижевника” (Поповић 2000: 434), како их је касније дефинисао.

\footnotetext{
*irena.arsic@filfak.ni.ac.rs
} 
У питању су били писци различитог порекла и друштвеног статуса, повезани заједничким пријатељством, културним настојањима, књижевним плановима и својом улогом у културном животу Дубровника. Састајали су се често и читали једни другима своје стихове и прозне саставе, заједно радили на публикацијама и проучавали споменике дубровачке прошлости. Њихов „пословни шеф”, како га Поповић назива, био је Матија Бан (1818-1903). Павле Поповић сматра да је Матија Бан, под утицајем идеја из Цариграда и Београда, уз услове које му је нудио дубровачки културни, политички и интелектуални живот, успео да већ постојећи скуп учених људи активира око нових идеја и организује у раду на часопису „Дубровник цвиет”. Уз Бана, Павле Поповић, као „шефа нове дубровачке плејаде, вођу целог покрета књижевног и политичког” (Поповић 2000: 435) препознаје Орсата Меда Пуцића (18211882). Дубровачки племић се управо вратио са школовања и дужег боравка из Европе, и тада писао своје Талијанке, али и еп о Карађорђу Петровићу, као што је и активно истраживао прошлост и већ објавио неке од ћирилских споменике. О Медовом брату, Нику Великом, Поповић је могао да говори само према утисцима Иде фон Дирингсфелд и његових следбеника, дум Ивана Стојановића, пре свих, јер тај учени Дубровчанин, о којем је остао глас као о великом зналцу и мудрацу, ништа није написао. Тако се сачувало сећање да је познавао европску филозфију, као и теологију, такође немачку књижевност, a, можда најбоље, класичну књижевност. Он је био тип старог дубровачког властелина, који је, као прототип ушао и у литературу - у Војновићеву трилогију, у Објављење Лука Зоре, у роман Иде фон Дирингсфелд.

Син писца и адвоката Антуна Казначића, Иван Аугуст Казначић (18171883), такође се у то време, као већ окушани уредник далматинских листова и аутор политичких чланака, вратио у Дубровник, да би се придружио овом изабраном друштву. Мада је писао пригодне песме, чак и једну комедију из студентског живота, проучавао дубровачке старине, састављао каталог библиотеке дубровачких фрањеваца, највише је волео, како то Ида фон Дирингсфелд пише, а Поповић подсећа, да време проводи у доколици. Од њега се, с правом, очекивало да састави историју Дубровника, а он је, после обиласка болесника у болници, пошто је по струци био лекар, водио дуге разговаре у чувеној кафани на Брсаљама. Тиме се млађи Казначић придружује оригиналним типовима које је Поповић у своје време сретао у Дубровнику.

Још оригиналнији, за српског научника, био је Антун Казали (18151894), класично образован, који је једном годишње поново читао целокупног Тацита, а преводио је Шекспира, Бајрона и Хомера. Необичан и у понашању, долазивши из дубровачке околине где је годинама био поп, Казали је, сем осталих својих разнородних састава, четири деценије писао спев Ћоса, чије је делове читао овој својеврсној дубровачкој академији, да га никад не објави.

У Дубровник је стизао, са својих парохија из околине и будући бискуп дубровачки, Мато Водопић (1816-1893). Водопић је био аутор приповедака из конаовског живота, као касније и из грушког, стварајући чисте и лепе српске типове и описујући старе српске фолклорне обичаје. Скупљањем и описивањем обичаја бавио се и Перо Франасовић, поп на Пељешцу, који се 
касније исказао и као приповедач. У тој групи су били и Ђорђе Бан, Перо Мариновић, Луко Свиловић, Нико Лепеш...

Личност коју Павле Поповић поставља као везу између периода половине 19. века и њему савременог Дубровника био је Матија Бан. Бан је већи део свог живота провео у Београду, па га је Поповић тамо сретао и директно пратио његов вишедеценијски рад у различитим областима културе, али и политике. Поповић текст о дубровачким писцима с половине века и пише поводом Банове смрти, али, како напомиње, „мирно и без суза”, уз нескривену неблагонаклоност. Да ли је у овом ставу, који је најављен, али и прожима читав текст, исказано и Поповићево мишљење да је Бан, на неки начин, одговоран за летаргичан Дубровник који је он сам затекао на прагу и током првих година двадесетог века?

Поповић је, наиме, у Дубровнику боравио у дужим боравцима више пута од 1899. до 1901, да би следећи долазак београдског професора био тек 1908. За такав подухват била му је потребна и дозвола бечких власти, али и, како може посведочити сваки истраживач, и ондашњи и данашњи, и симпатија и сарадња тамошње интелигенције.

Ко је, наиме, дочекао Павла Поповића у Дубровнику, тада увелико провинцијалном граду, али са дубоком свешћу о потреби очувања славне вишевековне традиције? На прелазу векова, Дубровник је већ био у зрелом добу национално-културног освешћења. Ту се, наиме, јасно дефинисао интелектуални покрет Срба католика са изграђеним културним али и политичким институцијама каква су била разнолика друштва, новине и друга периодична издања, издавачка делатност... У том смислу, Павле Поповић је имао удобан кутак у редакцији недељника „Дубровник” и доброг домаћина у његовом уреднику, Антуну Фабрису. Већ при првом боравку, Поповић је постао не само сарадник, него и често заменик преоптерећеном Фабрису. Поповићу је, вероватно, врло пријао тај изразити српски карактер Дубровника, који је био преовладавајући, уз круг око недељника „Црвене Хрватске”, који је својим дописима о „хрватству” старог града само указивао на српску доминацију. Све то је додатно утицало, уз научне основе тадашње славистичке филологије, на његов поглед на припадност старе дубровачке књижевности. Међутим, баш из разлога богатства старе књижевности, и у бројности писаца и множини дела, која су вековима у старом Дубровнку пратила европске токове, Поповић није могао да још израженије не осети недовољност прегнућа и изостанак значајнијих литерарних резултата њему савремених дубровачких интелектуалаца.

То све је утицало да Павле Поповић савремени Дубровник доживљава као суморни, затворени градић у дубокој провинцији, који је, посебно зими, „поред све благости климе, монотон, тужан, меланхоличан” (Поповић 2000: 446). У тој „дубровачкој арији” која је „опасна за нерве”, често се тражила веселост, на забавама и седељкама, као и током карневала, али је у тој веселости, како тврди Поповић, „било нечега очајног, мало необузданог” (Поповић 2000: 446). 
Међутим, уз овакву слику Дубровника, дато је и више примера за врло активан друштвени живот, у виду књижевних кругова у којима се воде разговори о литератури и политици, читају нови састави, расправљају се питања класичне литературе и филозофије, како ујутру уз кафу на Брсаљама, тако и у подне у Шарићевој спичарији, или у неком од дубровачких летњиковаца у Гружу и Ријеци Дубровачкој. Ти разговори су пуни духа и сатиричних жаока, мада не баш „генијални”, сматра Поповић, како их је називала Ида фон Дирингсфелд, када је половином века боравила у Дубровнику.

Највише симпатија и највише поштовања Павле Поповић је исказао за личност и дело Антуна Фабриса. Међутим, Фабрисов рад и његов положај у Дубровнику му је послужио и да укаже на његов усамљенички напор да уређује лист „Дубровник”, па затим и календар под истим именом, као и књижевни часопис „Срђ”. Тиме је он настојао, по Поповићевом мишљењу, да буди националну свест старог српског града, односно његову успавану књижевну свест. Фабрис је, по тврђењу Поповића, као ангажовани интелектуалац, био суочен са ситуацијом да „његов народ пада, малаксава, одустаје од борбе, губи терен који је једанпут тобож чврсто ухваћен”, да посматра „како бедно стоје српске ствари”, односно да уочава како се понекад „и у српским круговима фриволно мислило, нездраво политички радило” (Поповић 2000: 447). Што се стања у књижевности тицало, Фабрис је настојао да међу младим људима, „онима који су по способности и интересовању ближи редакцији, изазове вољу за књижевни рад” (Поповић 2000: 477), одбијајући да верује да су Дубровчани „razza che muore” (племе које умире). При томе је, међутим, наилазио на њихову „индиферентност и незаинтересованост” (Поповић 2000: 454).

Друга истакнута личност у Дубровнику коју је Поповић посећивао, био је дубровачки писац, филозоф и историчар, дум Иван Стојановић. Павле Поповић га приказује у тренутку када је овај дубровачки особењак, и по својој личности и појави у друштву, али и по свом врло оригиналном делу, требало да озваничи своју улогу у српском интелектуалном покрету. Уклањајући се од политичког ангажовања, Стојановић је дозволио Српској дубровачкој академској омладини да низом свечаности, које су планиране да буду везане уз његов јубилеј, манифестује „своју зрелост и способност”, излазећи „први пут сама пред публику”, први пут ступајући „као целина у јавни живот”. То све је требало да прати издавање дум Иванових дела, његове Дубровачке књижевности, као и Најновије историје Дубровника. Међутим, у јеку припрема, Иван Стојановић је умро, што је симболично, за Павла Поповића, указивало на убрзано гашење овог покрета.

Своје утиске о савременим Дубровчанима, Павле Поповић је изнео претежно у текстовима написаним поводом њихове смрти, чиме је и започео своју серију „одлазака са овога света”, па су стога они и груписани у периоду 1900-1906. године. Тако је Дубровник новијег доба, сем студије поводом смрти Матије Бана, Павле Поповић предочио кроз студије о Антуну Фабрису и дум Ивану Стојановићу, и у некрологу Луку Зоре. Овоме основном утиску су допуна краћи текстови о Људевиту Вулићевићу, Никши Сараки и Павлу Митровићу. 
На овај начин Павле Поповић је у релативно невеликом броју студија и чланака дао свој заокружени поглед на културни, књижевни, па и уопште интелектуални рад Дубровника новијег доба. Пишући о стању у Дубровнику половином 19. века, Поповић указује на живље кретање у политици и књижевности, које је проузроковало „мали симпатични покрет” (Поповић 2000: 434), у овој, како је назива „провинцијалној књижевности (Поповић 2000: 434), који је окупио „прилично коло књижевника и учених људи” (Поповић 2000: 435). То је био, сматра Поповић, круг писаца - присталица особитог дубровачког словинства, а касније пришлих српској националној идеји.

Оно што посебно карактерише овај круг је политичка свест, односно свест о губитку вековне самосталности и потреба за повезивањем у новом смислу, овога пута кроз национално освешћење као припадника Срба католика. У том смислу, Павле Поповић овај покрет види као међупериод ка заједници „са Србијом и осталим словенским земљама” (Поповић 2000: 435).

Поповић, при томе, прилично добро уочава састав те активне књижевне групе и њене главне чланове. Међутим, ови и животни вршњаци, који су, како Поповић примећује, и рођени двадесетих година 19. века, нису даље интересовали књижевног историчара. Они су свој рад наставили све до осамдесетих година, на сличним основама и са сличним настојањима. Поповић на тај начин занемарује и рад часописа „Словинац”, велики број његових сарадника и значајни број прилога из свих области, као и јасну усмереност и у националном смислу.

Од писаца из овог доба, Поповић једино прати најзначајније, Матију Бана и, донекле, Меда Пуцића. О Бану је, најпре, писао као извештач са његових београдских премијера, 1900, у листу „Дубровник”. Тада дубровачку публику обавештава да је управа Народног позоришта „све урадила да и овај Банов комад постигне заслужени успех", што потврђује чињеницу да се „много обраћа пажња на дубровачка дјела” (Пантић 2002: 659). Он оставља и документарно сведочанство о Бановим последњим годинама, када је „стар, обневидео, оглухнуо, савијен и сломљен годинама”, као „стари, ислужени, скоро заборављени књижевник”, „мирно трајао своје дане, чекајући смрт” (Поповић 2000: 432).

И тада, а и у тексту када коментарише Фабрисов напис о Бану, Павле Поповић је сасвим одређен да су његова дела „хладна, без живота, без поезије, са развијеном али не тачно мотивисаном интригом, са апстракцијама место карактера..." (Поповић 2000: 433), мада су у складу са принципима које је изнео. Баново позориште је морално, у њему се слави врлина и хероизам..." (Поповић 2000: 434), конкретан је Поповић, али и искључује сваку поезију.

Оцену дела Меда Пуцића, у своје време врло цењеног дубровачког аутора, Поповић је дао посредно, тумачећи Фабрисов текст о овом Дубровчанину, и јасно супротстављајући се аутору речима да је у питању „слаб дубровачки песник" (Поповић 2000: 451).

Највише пажње Поповић је посветио књижевним радовима дум Ивана Стојановића и ангажованим чланцима Антуна Фабриса. Поповић тако указује на особито литерарно и преводилачко дело Ивана Стојановића, чије 
сврставање, па и разумевање усложњава компликована жанровска структура. Што се тиче Стојановићеве допуне Енгелове историје Дубровачке републике, Поповић тврди да је аутор од ове историје начинио своје мемоаре. Он је, наиме, био „очевидац свију догађаја, познаник готово свију главних личности, посвећени познавалац свију тадашњих прилика” (Поповић 2000: 424). За Дубровачку књижевност Поповић сматра да обухвата „све што је Дубровник интелектуално остворио у току векова" (Поповић 2000: 424), и да је то, после Апендинијеве историје, прво и једино излагање у том својеврсном пространству.

У Фабрисовом раду, Павле Поповић је посебно издвојио такозвану „политичку књижевност”, коју је образложио и поделио у три вида, са наведеним илустрацијама, у полемике, критике и теоријске политичке књижевности. При томе истиче Фабрисову изузетну ангажованост, али и заснованост на аргументима, вишеструко оријентисан поглед, толерантност и прихватање и супротстављених ставова, посебно у темама о клерикализму и хрватском питању у Дубровнику.

Некролог поводом смрти Лука Зоре, кратак је преглед и његовог публицистичког, књижевног, али и педагошког рада. Ту су изнете и оцене књижевне вредности његовог најзначајнијег дела, спева Објављење, за коју је Поповић рекао да је „мала и стоји испод његове репутације”, као и уредничког рада у „Срђу”, часопису који је „носио обележје нешто архаичних назора свога старог уредника" (Поповић 2000: 465).

Књижевност новијег Дубровника, на основу појединачних запажања Павла Поповића, задржава своје карактеристике посебности, које се могу дефинисати у два става: „сваки учен човек сматра све врсте књижевних послова као своје, као послове на које га сама његова ученост позива" (Поповић 2000: 424), што би условило и другу одлику - то је изразито ангажована књижевност, књижевност са циљем, што је и разлог њене жанровске неофицијалности.

Поред ових веза са савременим Дубровчанима, Поповић је читавог свог радног века сарађивао са Дубровчанима који су радили ван Града и својом стручношћу постигли у науци значајне резултате. Ту су, као најважнији, Милан Решетар, филолог и филателиста, као и Петар Колендић, проучавалац старе дубровачке књижевности. Са обојицом је радио на објављивању дубровачких биографија, а мишљење о њиховом раду више пута је износио. Колендића је, тако, као млађег, препоручивао за његов рад на универзитету, а, у једном краћем тексту, записао је да он „зна свакога врага у овим приморским пословима”, да је „пун лепих малих архивских и библиотечких налазака, и обрађује их врло пажљиво и са добрим информацијама (Поповић 2002: 309)”, да у својим радовима „даје податке о писцу, о предмету, о литератури поводом тога, „све по архиву, по старим књигама, по оном што је лично видео" (Поповић 2000: 309). Решетара је, чак, морао и оштро полемички да штити од напада на његово издање Његошевог Горског вијенцяа, као што је исто чинио и са допуном истог дела од стране Јосипа Берсе. 
У каснијим годинама, Павле Поповић се није бавио писцима њему савременог Дубровника и њиховим радом. Чак није писао ни своје чувене некрологе, а могао је, како би то био евентуални случај са историчарем и публицистом, уредником „Срђа”, Антуном Вучетићем, кога је, сасвим сигурно, сретао у Дубровнику још у својим првим доласцима, као угледног а прогоњеног професора Дубровачке гимназије и блиског рођака Антуна Фабриса. У томе га је, сасвим је извесно, спречавао његов врло захтеван и активан научни, професорски и публицистички рад, како се и оправдава приликом позива да својим прилогом допринесе првом, нажалост и једином броју „Гласника” Дубровачког ученог друштва „Свети Валхо”, тридесетих година новог века, али и његово очигледно неодобравање начина на који су „српске ствари” текле у старом граду. Тако је, на пример, његов ученик и несуђени наследник на катедри старе дубровачке књижевности у Београду, Никола Антула, у критици издавачког рада дубровачке Матице српске, која „није подешена према правим књижевним потребама приморских Срба” (Антула 1912: 295), сигурно имао подршку свог ментора. Можда је то био и разлог, наравно уз позне године, што се Поповић није нашао међу онима који су 1936, уз остала српска културна друштва, обнављали рад и ове институције.

Сасвим се извесно може закључити да је Павле Поповић савремени Дубровник и његове ствараоце и интелектуалце, уопште, сматра мање важним од писаца и литературе старе Републике којој је посветио читав свој продуктивни научни рад. Међутим, такође се може рећи да је у настојањима њему савремених Дубровчана увидео одређено јединствени покрет који, ипак, није изазвао његово веће интересовање.

\section{ЛИТЕРАТУРА}

Антула 1912: Н. Антула, Матица српска у Дубровнику, Џиво Бунић Вучићевић, Београд: Српски књижевни гласник, XII, XXVIII, 4-5, 295-300, 363-369, 295.

Пантић 2002: М. Пантић, „О Поповићевој књижевној критици и књижевној историографији”. П. Поповић, Књижевна критика - књижевна историографија, приредио М. Пантић, Сабрана дела, књ. 10, Београд: Завод за уџбенике и наставна средства, 621-671.

Поповић 2000: П. Поповић, Дубровачке студије, приредила 3. Бојовић, Сабрана дела, књ. 4, Завод за уџбенике и наставна средства, Београд: Завод за уџбенике и наставна средства. 


\section{Irena Arsić}

\section{PAVLE POPOVIĆ AND ”NEW DUBROVNIKS PLÉIADE”}

\section{(Summary)}

During his stay in Dubrovnik, where he conducted a research on Dubrovnik's literature, Pavle Popović encountered and socialized with the erudite Serbs Catholics. The most significant of them were: historian and philosopher Ivan Stojanović, and publicist Antun Fabris. Popović wrote an epigraph for Matija Ban where he described $19^{\text {th }}$ century Dubrovnik's intellectual circles. Additionally, Milan Rešetar and Petar Kolendić collaborate with Popović on publishing of old Dubrovnik's literature.

This paper examines the Pavle Popović's stance on Dubrovnik's writers and scientific workers from the new age. 